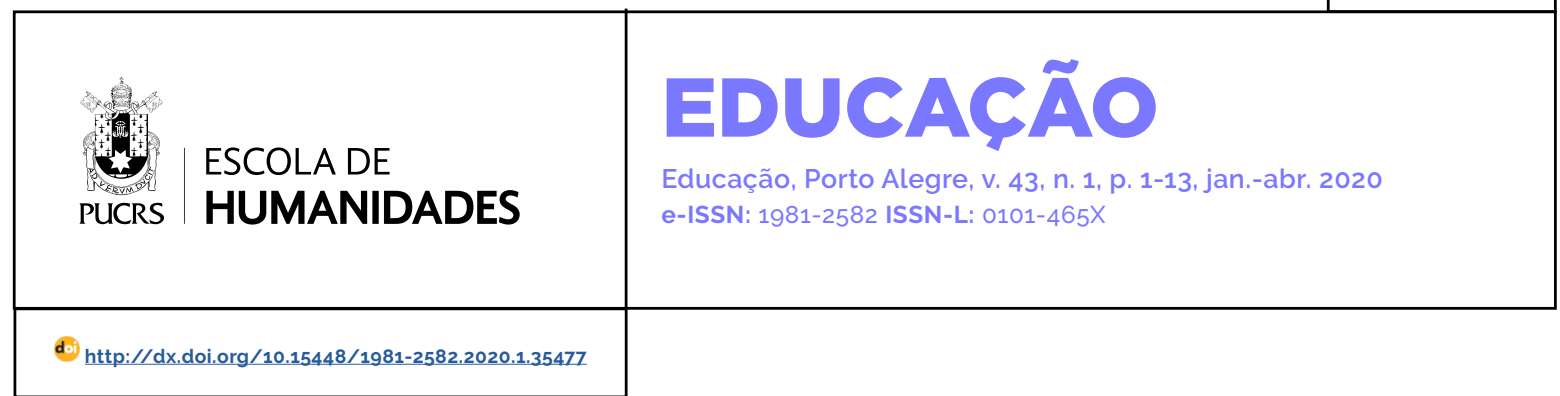

DOSSIÊ

\title{
Can you hear me? - Accessing the voice of the child with Autism and their parent
}

\author{
Você pode me ouvir? - Acessando a voz da criança com Autismo e seus pais \\ ¿Puedes escucharme? - Acceder a la voz del niño con Autismo y sus padres
}

\author{
Miriam Twomey ${ }^{1}$ \\ orcid.org/0000-0002-9537-8297 \\ miriam.twomey@gmail.com
}

Recebido em: 31 ago. 2019 Aprovado em: 16 jan. 2020. Publicado em: 25 mai. 2020.

\section{(c) (1)}

Artigo está licenciado sob forma de uma licença Creative Commons Atribuição 4.0 Internacional.
Abstract: The aim of this paper is to access the voices of children with Autism Spectrum Disorders and their parents. This paper engages with philosophical conceptual frameworks exploring concepts of movement and engagement in eliciting child and parent voice. Qualitative, longitudinal case studies were conducted. Semi-structured interviews [ $=83$ ] were conducted with stakeholders including parents. Children with and without the label of Autism engaged in interventions drawing on the Creative Arts. Living autoethnography was considered a methodological tenet, establishing connectivity between life and research, self and others, providing a window through which the internal world of the parent was interpreted and understood. This research enabled children and parents to explore their worlds and deliberate on areas that affected their lives. The potential value for using the Creative Arts as a means of engaging children with Autism is discussed. Implications relating to movement [literal and metaphoric] and engagement are explored. Key words: Engagement; Autism; Child and Parent voice.

Resumo: O objetivo deste artigo é acessar as vozes de crianças com Transtorno do Espectro Autista (TEA) e de seus pais. Este artigo aborda estruturas conceituais filosóficas que exploram conceitos de movimento e engajamento como forma de dar voz a crianças e pais. Estudos de caso qualitativos e longitudinais foram conduzidos. Entrevistas semiestruturadas $[n=83]$ foram realizadas com as partes interessadas, incluindo os pais. Crianças com e sem o diagnóstico de TEA envolveram-se em intervenções baseadas nas Artes Criativas. A autoetnografia viva foi considerada um principio metodológico, estabelecendo conectividade entre a vida e a pesquisa, o eu e os outros, fornecendo uma janela através da qual o mundo interno dos pais foi interpretado e compreendido. Esta pesquisa permitiu que crianças e pais explorassem seus mundos e deliberassem sobre as áreas que afetaram suas vidas. O valor potencial do uso das Artes Criativas como meio de envolver as crianças com Autismo é discutido. Implicações relacionadas ao movimento [literal e metafórico] e engajamento são exploradas.

Palavras-chave: Engajamento; Crianças com Autismo, Voz da criança; Voz dos pais; Inclusão, Movimento; Imitação; Teatro de Fantoches

Resumen: El propósito de este artículo es acceder a las voces de los niños con Trastorno del Espectro Autista (TEA) y sus padres. Este artículo aborda los marcos conceptuales filosóficos que exploran conceptos de movimiento y compromiso como una forma de dar voz a los niños y los padres. Se realizaron estudios de casos cualitativos y longitudinales. Se realizaron entrevistas semiestructuradas [n = 83] con las partes interesadas, incluidos los padres. Los niños con y sin diagnóstico de TEA participaron en intervenciones basadas en Creative Arts. La autoetnografía viva fue considerada un principio metodológico, estableciendo la conectividad entre la vida y la investigación, uno mismo y los demás, proporcionando una ventana a través de la cual se interpretaba y entendía el mundo interior de los padres. Esta investigación permitió a niños y padres explorar sus mundos y deliberar sobre las áreas que afectaron sus vidas. Se discute el valor potencial de usar Creative Arts como un medio para involucrar a los niños con Autismo. Se exploran las implicaciones relacionadas con el movimiento [literal y metafóricol y el compromiso.

Palabras clave: Compromiso; Niños con Autismo, voz del niño; La voz de los padres; Inclusión, movimiento; Imitación; Teatro de marionetas 


\section{Introduction}

It is acknowledged in the literature that children with Autism frequently fail to initiate or reciprocate social actions and communicative behaviours similar to their peers and are frequently isolated due to these challenges. This may be further exacerbated by the emergence of asymmetrical relationships in the context of increasingly nuanced forms of language associated with later childhood.

It is possible to speculate that research focusing on children with Autism frequently objectifies them in terms of their cognitive, social or communicative deficits. Research focusing on parental experiences of parenting children with Autism range from their reactions to the diagnosis to their perceptions of their ability to parent their child effectively (Twomey \& Shevlin, 2016).

Accessing the voice of children with Autism is a relatively new and emerging field which emphasises the importance of ascertaining their views on their lives. Equally the voice of the parent is rarely heard except when it pertains to their children's assessment and diagnosis and parents' reactions to these events.

This paper seeks to capture the intricacies of how we can access the voice of the young nonverbal child with Autism. The voice of the parent is also considered.

Drawing from a review of the relevant literature this paper is structured around a discussion of the following central themes: the social and communicative challenges of young children with Autism, the role of movement and imitation, and creative approaches to accessing voice.

\section{Background}

Research dedicated to children's voice involves the positioning of a rights-based focus and the degree to which young children are included (United Nations Convention On The Rights of the Child, 1989). Research facilitating children's voice should prioritize Article 13 of the UNCRC: The right for children to express themselves in different ways (through talking, drawing, writing, photography). It is also possible to conceptualise voice as an expression of the child's agency where children are regarded as active agents and that they are included in research with them, not on them. Although child voice may be present, their voice may be understated and occasionally silent (Lewis, 2010). This research proposes that when children are nonverbal, the absence of audible voice should not preclude them from being heard. A child's ability to communicate, develop and learn should allow for voice to be articulated differently (Twomey, 2018).

Provision for young children with disabilities in Ireland is rights based and reflects international developments in policy and practice. More recently services for children with Autism have proliferated, however provision for children with disabilities in Ireland developed historically in an inconsistent manner. Issues of disadvantage, disability and social inclusion prompted the development of targeted services. These services included pilot projects for children with Autism Spectrum Disorders (ASD) (Rose, Shevlin, Twomey \& Zhao, 2017). Traditionally, education for children with disabilities witnessed a two track approach - special and mainstream. More recently, a systematic approach to inclusion sees children with disabilities included in their community Early Years Education or preschool setting. These developments are underpinned by national legislation including the Education for Persons with Special Educational Needs (Epsen, 2004) Act and the Disability Act (2005). Notwithstanding this, children who require multiple services, or who have more complex needs receive services from varying government departments and organisations, compounding a lack of uniformity in Early Intervention services. Recent policy initiatives including the publication of the National Policy Framework for Children and Young People 2014-2020, 'Better Outcomes Brighter Future' (Government of Ireland, 2014) highlights Early Intervention as a transformational goal and encourages parental involvement in assessment and decision making (Rose, Shevlin, Twomey \& Zhao, 2017). Inclusion is regarded as a central tenet of Early Intervention and for the purposes of this article, inclusive education is seen as creating opportunities for all children's 
participation in mainstream settings regardless of their differences (Johora, Fleer \& Veresov, 2019).

Young children with ASD in Ireland are provided with Early Intervention in a variety of settings, including the home, centre based Early Years settings or specialist preschool and mainstream school settings. This article will describe Alex, a young boy with ASD aged four years who attended an Early Intervention class in his local community and who transitioned to a mainstream primary classroom during the period of the research. It will also describe his parent's perceptions and understandings of Early Intervention and parents' need for training, information and intervention relative to social interaction and communication.

Against this background the purpose of this research sought to answer the research question(s): how can we access the voice of the young child with ASD using creative methods? And do we consider the voice of the parent?

\section{Literature Review}

Key themes explored in the literature are based on theoretical concepts including early communication and social engagement challenges for children with ASD, movement and imitation, and creative approaches to accessing voice of young children with ASD and their parents.

\section{Social and Communication Challenges in ASD}

Autism is a neurodevelopmental disorder characterised by social and communication impairments as well as a restricted range of interests and activities (American Psychiatric Association, 2013). While young children with Autism may not have established the most fundamental elements of early social interaction and communication (Dawson et al. 2002), it is thought that these children may engage socially in a nuanced way though it may be significantly differently to typically developing children (Kasari et al., 2011). It is widely accepted that Early Intervention provides optimal experiences for young children with Autism and addresses issues with social and communication development (Parsons et al. 2009). According to Bauminger and Schulman (2003) social engagement may develop but that it may be mediated by others.

Hobson (1993) suggests that children with Autism have a disturbance in intersubjective engagement with others. Put more simply, Hobson emphasises the different patterns of relational or affective relations between children with Autism and others and that these may be considered core issues. Sterponi and Fasulo (2010) emphasise the role of intersubjectivity as essential to human sociability and communication. The authors suggest that we need to investigate nonverbal modes of interaction that may illustrate intersubjectivity for children with ASD. Due to difficulties understanding and expressing embodied social actions and communicative behaviours, children with Autism frequently fail to exhibit social fluency and are hindered in their ability to develop relationships with peers.

\section{Movement and Imitation}

Considering the primacy of movement in the development of relationships, Hobson (2007) and Reddy (2008; 2012) explore what happens when a child is not moved in thought and feeling (Hobson, 2007 137) (literally and metaphorically) in response to another. According to Reddy (2008; 2012) children with ASD are less likely to turn around, move, smile or laugh. In a study by Garcia-Perez, Lee and Hobson (2008), the authors investigated head movements, gestures, eye gaze, whole body response, nodding, and physically moving across a space. The authors proposed that children with ASD are less likely to engage with the bodily expressed communication of others. Trevarthen and DelafieldButt (2015) account for changes in development that affect timing, motor development and affective engagement and propose an interactive relational approach to therapy that nurtures intimacy and creative movement.

According to Baron-Cohen (1989) children with ASD experience challenges with Theory of Mind (TOM) or understanding the intentions and feelings of others. Alternatively, Fuchs and De Jaegher (2009) explore embodiment and sense making in ASD and suggest that a non-representational model 
of social cognition is more apt for children who experience difficulty with mental representations; understanding the thoughts and experiences of others. The authors prioritise a 'mindbody' approach where social interaction is an active embodied experience and where intersubjectivity is embedded in whole body actions.

De Jaegher (2013) enhances this phenomenological view describing an 'enactive' approach to ASD, highlighting how ASD is increasingly described as a difference in perceiving, moving and feeling. De Jaegher suggests an integrationist view which includes cognition, communication and perception, how the individual with ASD perceives, embodies and connects with a world is closely related to how they make sense of it.

\section{Imitation}

The potential for increased communicative behaviour and active social development in children with ASD has been emphasised in research on imitation by Caldwell (2010), Escalona et al. (2002), Ingersoll (2012), Nadel (2014) Nadel et al. (2011) and Wimpory, Hobson, and Nash (2007). Escalona, et al. (2002) emphasise the importance of adult responsiveness but also imitation of the child's behaviour, by the adult. The authors recommend imitation as a particularly appropriate intervention for young nonverbal children with ASD. The research methods used in this project were based on the long standing work on imitation and its effects on children with ASD. Escalona, Field, Nadel and Lundy (2002) showed that after imitation children with ASD had improved distal and proximal social behaviours.

\section{Creative Approaches to Accessing Voice}

This article suggests that research with children with social and communicative difficulties requires the development of innovative methods to access a differently articulated form of voice expressed through movement and non-verbal communication. Jones and Gillies (2010), Long et al. (2012) and Rose and Shevlin (2010) encouraged the development of more creative methods. Considering the use of creative methods and their suitability for children with ASD, this research adopted the use of puppetry in engaging young children with ASD. Traditionally puppets have been employed by various disciplines in clinical and community settings, and for children with ASD, some attention has been devoted to their use as a communication and instruction tool (Schrandt Buffington-Townsend \& Poulson, 2009; Dwight-Salmon, 2005; Epstein et al., 2008; Salmon \& Sainato, 2005). Puppets have been used as a medium for engagement but also to teach imitation and to improve social functioning (Escalona et al., 2002). Trimingham (2010, 25) drawing on Winnicott (1971) suggests that puppets may act as 'transitional objects' in a creative space. She argues that children who have perceptual or communication difficulties may benefit from the use of puppets who have a bodily reality, encouraging a sense of embodiment through physical interaction.

The role of the parent is generally portrayed in negative terms where parents are viewed through bereavement or stage based approaches. Recent Irish research (Twomey \& Shevlin, 2016) considers the parent voice to be an essential component in understanding the perceptions and experiences of parents and how they interpret their children's needs. The third theme, also links movement to parents' experiences as that of journeys (Twomey \& Shevlin, 2016). Parents' evolving identities and how this might be impacted during the trajectory of their child's assessment, diagnosis and early education experiences. Parents in this research were considered as nomads or warriors whose role they felt was to counter the state, occupying what Deleuze and Guattari $(1986 ; 1987)$ describe as the 'intermezzo' allowing us to think that the in-between space is of assessment, diagnosis and intervention is characterised by movement and change.

Living autoethnography was considered appropriate in terms of the author's positionality, as the researcher is a parent of a child with ASD. This approach to parent voice provided a window through which the internal world of the parent was interpreted and understood (Ngunjiri, Hernandez \& Chang, 2010). 


\section{Research Design}

\section{Ethics}

Concern about the representation of children's voice is particularly worth noting when children have severe disabilities or are nonverbal. This is important when researchers as intermediaries attempt to represent the views and wishes of these children. Due to the young age of the children in this study, parents were approached regarding consent. Confidentiality and anonymity were explained to all participants. Participants were advised in written form and were verbally reassured that their names would be anonymised and any distinguishing features relating to children, school or locality would be dealt with confidentially. Anonymisation in the form of removing names and any other form of identification was explained.

Considerations regarding ethical procedures relating to children's participation, required that confidentiality was described in a way that children could understand. Participatory practices during the research were supported by collaboration with speech and language therapists, educators, occupational therapists and Special Needs Assistants (SNAs) relative to each setting. The researcher used visual aids and pictorial representations including the Picture Exchange Communication System (PECS), and Irish Sign language to address the ambiguous and contested nature of children's participation (Graham \& Fitzgerald, 2010). Listening to children's voices and encouraging them to actively participate was integral to the research design (Smith, Taylor \& Gollop, 2000). An ethics-in-practice approach was continuously observed. Even when the child was unable to give informed consent, they were provided with opportunities for assent and dissent through the use of Objects of reference, PECS and simple Irish Sign Language. These efforts aimed to emphasise the voluntary nature of their inclusion (Lewis \& Porter, 2007). Similar to Tozer (2003) children with ASD were provided with a 'stop' card and a 'change' card if familiar to them, to signal their ability to withdraw or discontinue when overwhelmed or unable to understand.

For the purposes of this article, the following section will focus on the development of creative methodologies, which was considered one of the significant elements in this research.

\section{Methods}

\section{Research design}

This research took the form of a qualitative, longitudinal case studies conducted over a period of 18 months. Parents, professionals, teachers and Early Intervention practitioners $(n=83)$ were interviewed. One focus group took place with parents at the beginning of the research. Twenty one-to-one interviews were conducted with four mothers and one father. The research project was conducted over four phases with 5 children with Autism. This included observations ( $n=24$ ) and puppet interventions ( $n=30$ ) during a fifteenth month period. The research phases coincided with school academic terms.

TABLE 1 - Description of Children and Educational Placements

\begin{tabular}{|c|c|c|c|c|c|}
\hline CHILD & ADAM & JACK & CHARLIE & ALEX & MAX \\
\hline AGE & 2.5 years & 3 years & 3.5 years & 4 years & 6 years \\
\hline SETTING & $\begin{array}{c}\text { Early } \\
\text { Intervention } \\
\text { Unit [Urban } \\
\text { Special School] }\end{array}$ & $\begin{array}{c}\text { Early } \\
\text { Intervention } \\
\text { Unit [Urban } \\
\text { Special School] }\end{array}$ & $\begin{array}{c}\text { Early } \\
\text { Intervention } \\
\text { Unit [Suburban } \\
\text { Mainstream } \\
\text { School] }\end{array}$ & $\begin{array}{c}\text { Early } \\
\text { Intervention } \\
\text { Unit [Suburban } \\
\text { Mainstream } \\
\text { School] }\end{array}$ & $\begin{array}{l}\text { Mainstream } \\
\text { School [Rural }\end{array}$ \\
\hline $\begin{array}{l}\text { ASD } \\
\text { SPECIFIC } \\
\text { APPROACH }\end{array}$ & $\begin{array}{l}\text { Objects of } \\
\text { reference }\end{array}$ & $\begin{array}{l}\text { Objects of } \\
\text { reference, } \\
\text { PECS } \\
\text { TEACCH }\end{array}$ & $\begin{array}{c}\text { TEACCH } \\
\text { Adapted } \\
\text { Curriculum }\end{array}$ & $\begin{array}{c}\text { PECS } \\
\text { TEACCH } \\
\text { Curriculum }\end{array}$ & $\begin{array}{c}\text { PECS } \\
\text { TEACCH } \\
\text { Differentiated } \\
\text { Curriculum }\end{array}$ \\
\hline
\end{tabular}


The researcher purposefully selected samples of Early Intervention settings for children with Autism and stratified this purposeful sample according to type; specialist or inclusive, access to special or mainstream primary resources, personnel and physical environments and their geographical positions. Alex was a young four year old boy who was selected to participate in this study as he had received a diagnosis of ASD at age four and had difficulties attending his local neighbourhood generic preschool. Prior to the research it was recommended that Alex leave his local preschool and attend 'Nurture' which was deemed suitable for him by the Early Intervention professional multi-disciplinary team. Alex displayed differences in the development of his thinking, language, behaviour and social skills.

At the start of the research, Alex attended a specialist ASD specific Early Intervention Early Intervention preschool called 'Nurture', attached to a mainstream primary school'. During the first phase of the research, Alex entered the transition programme - 'First Steps' into the adjacent mainstream primary junior infants' classroom. Alex was involved in classroom-based elements during Maths and literacy periods. In the Early Intervention class, Alex had received a structured approach to learning. He had benefited from The Treatment and Education of Autistic and related Communication Handicapped Children (TEACCH) approach, elements of behaviourist approaches, PECS, Social
Stories and Irish sign language (LAMH). The following section will identify the development of research methods during the phases of the research.

\section{Research phases}

Fifteen children including two buddies from Alex's Infant class group were invited to attend a smaller classroom. The children were classmates of Alex in the mainstream school. Each phase lasted approximately 2-3 months, similar to the academic school half term. During each research phase there were a number of visits by the researcher. In between the researcher's visits the class and resource teachers implemented similar interventions.

Prior to each session, the researcher encouraged Alex' Special Needs Assistant (SNA) Julie to incorporate the Occupational Therapist's recommended sensory modulation programme. Alex experienced difficulties with sensory Integration Disorder - a condition that arises when sensory signals don't become organised into appropriate responses. Alex did not perceive or respond to the environment similar to his peers. This was established to co-regulate Alex physiologically prior to classroom participation. When Alex was regulated Julie included Alex in the group.

Table 2 will describe the 4 phases of the research and the interventions used with Alex and the class group of children ( $n=15$ ). Levels of engagement are described during the phases of the research.

\section{TABLE 2 - Phases of research and interventions}

\begin{tabular}{|l|ll}
\hline PHASES & INTERVENTION & LEVELS OF ENGAGEMENT \\
\hline PHASE 1: & $\begin{array}{l}\text { 'Facilitated participation with Julie (SNA) during Art } \\
\text { activity [rest of class group of 15 children used talk } \\
\text { and draw methods]. }\end{array}$ & $\begin{array}{l}\text { Low engagement rates during talk } \\
\text { and draw activity }\end{array}$ \\
\hline PHASE 2 & $\begin{array}{l}\text { 'Facilitated engagement with peer mediation during } \\
\text { Art activity' - this involved researcher prompting Alex } \\
\text { to respond to the peer(s) he chose to play with [rest } \\
\text { of group used talk and draw methods]. }\end{array}$ & $\begin{array}{l}\text { Increased engagement responses } \\
\text { to peers' initiations and social } \\
\text { engagement rates increased }\end{array}$ \\
\hline
\end{tabular}

1 The Department of Education and Skills (DES) in Ireland has developed a strategy to provide early intervention for children with ASD from the age of 2.5 years. Children over 3 years of age may be enrolled in an Autism specific early intervention class. 'Nurture' is an example of a specialist Early Intervention class attached to a mainstream primary school, specifically catering for the needs of children with a diagnosis of Autism Spectrum Disorders. 


\begin{tabular}{|l|lll|}
\hline PHASES & INTERVENTION & LEVELS OF ENGAGEMENT \\
\hline \multirow{3}{*}{ PHASE 3: } & $\begin{array}{l}\text { 'Facilitated engagement using puppet imitation' - } \\
\text { this involved the researcher conducting 1:1 imitation } \\
\text { method between Alex and a puppet. Followed by } \\
\text { inclusion of peers [15 children in class group] }\end{array}$ & $\begin{array}{l}\text { Moderate engagement rates in 1:1 } \\
\text { interactions with puppet. Increased } \\
\text { unprompted initiations and } \\
\text { responses to peer }\end{array}$ \\
\hline \multirow{3}{*}{ PHASE 4: } & $\begin{array}{l}\text { Phase 4: 'Facilitated engagement using puppet } \\
\text { imitation, peer mediation and inclusion of microphone' }\end{array}$ & $\begin{array}{l}\text { Higher engagement rate in 1:1 and } \\
\text { group interaction }\end{array}$ \\
\hline
\end{tabular}

Phase 1 involved observation and focus group interviews conducted by the researcher with children in the junior mainstream classroom using talk and impromptu drawing (Leitch \& Mitchell, 2007).

During Phase 2, puppet role play was introduced as a departure from researcher led activities. Fifteen children including two buddies from Alex's school 'Buddy System' organised by the Resource Teacher were included in the intervention group. Alex's Infant class group ( $n=15)$ were invited to attend a smaller classroom. Seating arranged in a semi-circle was more conducive to participation. Children were recorded using video and observation methods. Puppets were introduced by the researcher to perform role plays on topics related to friendship.

During Phase 3 and Phase 4 puppet role play was developed at the beginning of each session and followed by puppet hosted focus groups. Alex's two buddies were positioned close to him. There was potential for increased participation through involvement of typical peers in the intervention (Wolfberg, Bottema-Beutel \& de Witt, 2012).

During phase 4 following role play children were invited to co-design the focus group interviews, and were provided with interviewing equipment in the form of a real, functioning microphone to add to their authenticity as researchers. Children's participation was extended by including their topics of interest or play themes.

The frequency with which children were actively involved in the research aimed to prompt a higher degree of engagement. More frequent visits to (pre)schools aimed to increase children's familiarity with the researcher and the puppets, encouraging reliability of imitative interactions and children's growing levels of responsiveness. Alex spent significantly more time engaged in the latter phases of the intervention. Classroom observation showed significant increases in imitation, joint attention and engagement.

\section{Approach to Analysis}

Microanalysis of children's embodied experiences captured by video were edited to 20-minute segments of content; which were presented to an interobserver who is a specialist in Autism and movement. The videotaped recordings were used to code the interventions. Coding recorded gestures such as eye contact, alternate gaze, reaching, pointing, and movement as done using Rochat, Passos-Ferreira and Salem's (2009) levels of intersubjectivity. When coding primary intersubjectivity states, coding included reciprocal and contingent behaviours. Secondary intersubjectivity recorded when the child and adult were actively involved with the same object or event. Tertiary intersubjectivity states were recorded when it became apparent that Alex exhibited a sense of ownership or pro-social behaviours.

The following section will present the findings relative to the research phases.

\section{Findings}

During phase 1, Julie scaffolded Alex's efforts at drawing. She facilitated him using a visual schedule and communication tools. Alex however found hand writing difficult and did not appear interested in participating. Alex's difficulty and reluctance to engage through the use of traditional research methods (talk and draw) 
suggested a need for further refinement of the research tools to support his inclusion. What was required was an approach that would increase Alex's engagement.

Alex was reported to isolate himself from other children; preferring to focus on objects. Classroom observations witnessed Alex's ability to engage attention in self-selected activities, focusing on numbers and letters for long periods, silently. Alex's peers sat next to him, peering over his shoulder observing his quiet and dedicated concentration. Explicit guidance was required by Julie during peer interactions. Julie provided vigilant scaffolding of social and communicative cues, encouraging Alex to respond to peers' initiations and participate in reciprocal exchanges.

During the period of the research, it emerged that Alex enjoyed Art, Drama and Physical Education (PE), however initially he did not respond well to teacher instruction or other children's social initiations. He had difficulty maintaining attention and exhibited increased sensory challenges. Alex's Mum Amy described his difficulties prior to the research: he isolates himself from the other children, he will spend hours on end just moving pencils from one table to another, lining them up, sharpening them, he doesn't ever want to co-operate" (P1, Phase 1). "He will play there for hours" - Amy noted play as source of disconnect between her and Alex and explained that she had procured private play therapy to improve the parent child relationship.

\section{Movement and Imitation}

Prior to the research, Amy noted that Alex wouldn't look at her.... "Or play with his brother"... preferring to "stand alone in the school yard..." ( $\mathrm{P} 1$, Phase 2) however during the period of the research, Amy felt that Alex was "included in the playground and always had other children, he was always included, he was included in drama and he was included in Physical Education". (P2, phase 2).

\section{A New Friend}

During Phase 2, in an effort to deepen children's engagement, the researcher abrogated her traditional role. She brought puppets in a large coloured bag. On arrival one of the puppets started to speak from this brightly coloured bag. The researcher removed the puppet, held the puppet facing the children displaying animated, open and empathetic gestures. The goal was to maintain puppets' levels of interest and novel interactions to sustain children's engagement.

The researcher introduced herself as Pretty Girl, adopting the persona of a large child sized puppet. The effects of the size of the puppet were instantaneous; children immediately identified with the researcher's large hand held guise. The researcher introduced a second child sized puppet and explained that Pretty Girl and Pretty Boy (a second male puppet) were going to talk about 'friends'. The puppets displayed appropriate visual cues and gestures to accompany interactions and emotions. They were facing each other and the group, laughing, smiling and hugging. This role-play was designed as a motivational prop to engage children in conversation and build rapport prior to the focus group. The puppets displayed exaggerated emotional, verbal and non-verbal interactions depicting friendship and its loss. Focus group questions posed to the children reflected thematic areas of interest about 'play', 'friendship', 'belonging' and 'inclusion'. At the end of phase 2 Alex reluctantly participated in a class focus group where puppets were introduced as co-researchers. He seemed to enjoy the presence of the puppets though rarely cast his eyes upwards or gazed directly at them.

During phase 3 the children asked "if the puppets are coming?" when they saw the researcher arrive at the school. A puppet directed role play immediately ensued, inviting comments and prompting observations from the children. Responding to the puppets, one child said "when my friends leave me I feel sad" ( $\left.\mathrm{C}_{1}, \mathrm{P}_{3}\right)$. Another child commented on inclusion saying: "I like to join in" (C2, P3). The puppets succeeded in encouraging children to voice emotions and articulate feelings. Children spoke directly to the puppets affirming their perception of the puppets' reality. One buddy said "I'm playing with Alex today. We play together 
in the school yard" (C3, P3). Their accounts were flowing and child-centred. One of the buddies frequently checked to see if Alex needed help, while waiting for her turn to engage with the puppet. She encouraged him to look at and talk to the puppets. She supported Alex with visual communication tools, finding a PECS icon for puppet; referring to the puppets as 'new friends'.

During several encounters, the puppet imitated Alex's nonverbal actions. Alex gazed at the puppet's animated, features and subsequently imitated its actions. While moving the puppet, the researcher's vocal tone was imbued with animated and emotional qualities. Alex developed more consistent eye gaze, moving enthusiastically towards them, trying to touch them. Alex become involved in unscripted, unprompted, interactions as well as developing spontaneous vocalisations.

Phase 4 increased puppet directed activities and invited the children to participate as puppeteers. A real functioning microphone was introduced to add to their authenticity as researchers. When the microphone was introduced, the researcher noted Alex's fascination. His gaze averted towards the object, his fascination becoming apparent; its functionality was evident. Pretty Girl spoke through the microphone, encouraging paroxysms of delight. Such was their excitement that the children including Alex began to run towards the puppets.

While children became actively engaged, dialogue with the puppets also provided a window into their conceptualisations of play, belonging and inclusion.

\section{Discussion}

The following section of this article will interpret the findings in light of extant literature. While this research has taken the form of a small-scale qualitative embedded case study, involving participant groups including a child with the label of ASD, it also yielded valuable information relating to the development of creative methods which were designed to engage children and access voice during a longitudinal study.

Drawing on concepts of social communication relative to $A S D$, movement and imitation and creative approaches to accessing voice, the remainder of this article will discuss the findings in relation to the extant literature.

\section{Theme 1 Social and Communication Challenges in ASD}

Although Alex experienced difficulty with social relating, (HOBSON, 1993; HOBSON, 2007), understanding the intentions and feelings of others (Baron-Cohen, 1989) and making sense of the world, Alex was observed as an emerging preverbal self. Alex did not engage with the typical language and communication repertoires representing sociality in the mainstream classroom, however he responded optimally to puppetry. Rochat, Passos-Ferreira and Salem's (2009) levels of connectedness, were accommodated in the design of the research with the incorporation of objects and the support of social experts such as Julie and his peers (Wolfberg, Bottema-Beutel \& De Witt, 2012).

Drawing on Winnicott's use of transitional objects, it is possible that the puppets became the bridge between dyadic and triadic interactions and an important consideration in the processes between primary, secondary and tertiary intersubjectivity where the puppets as transitional objects extended embodied interactions and reciprocation with others. While initially imitation appeared passive, Alex showed intentionality when the microphone was introduced. There was evidence of a natural, competent and agentic child. This research suggests that parents would benefit from inclusion in projects focusing on intersubjectivity in the home. Parents felt disconnected from children's social world.

\section{Theme 2 Movement and imitation}

Alex was engaging at a bodily level which would precede knowledge of another's mind (Baron-Cohen, 1989). Puppets were useful imitating children's actions and teaching through imitation. Similar to Caldwell (2010), Escalona et al. (2002), Nadel et al. (2011), and Ingersoll (2012) the puppets potential for children's social and communicative development through imitation 
was sustained through frequent research visits and growing familiarity.

Alex responded more favourably to puppet intervention than conventional methods. This acknowledged the need for nonverbal modes of interaction and meaning making as suggested by Sterponi and Fasulo (2010) and De Jaegher (2013). For Alex, the puppet's ability to imitate and respond nonverbally was key to establishing engagement. This theme, also links movement to parents' experiences as nomads and their inner journeys. While parents as pathfinders successfully procured private therapies (Twomey \& Shevlin, 2016) they failed to share an inner world with their own child.

\section{Theme 3 Creative Methods to Accessing Voice}

The development of creative methodologies as a medium to engage the voice of young nonverbal children was enabled through refinement of the research tools. Similar to Trimingham (2010) the physical reality of the puppets meant that they could also be manipulated by the children. Optimising their use was the introduction of a real, functioning microphone which added to the puppets' reality and the innovative quality of the research. This captured Alex's propensity for object knowledge.

Parent voice was prominent in this research. The role of parent of a child with Autism frequently lacks conceptual clarity. Often, the parental role emerges during processes of assessment and diagnosis. Parents who were once adept at ordinary parenting, may experience an objectification of their role as parent of a disabled child which may be cultivated through interactions with professionals and schools, policy and legislation. This may lead to disempowerment (Twomey \& Shevlin, 2017). This research sought to forefront the narratives of parents acknowledging parents' stories and life events in eliciting their responses to their children's educational experiences. The author's experience as mother, academic and activist provided a more intimate meeting and series of interactions with parents. Supporting the research design, living autoethnography is acknowledged as an innovative approach to including the views of parents. A central theme of movement was elucidated by parents positioning in the intermezzo (Deleuze \& Guattari, 1986; 1987). On receipt of play therapy and appropriate parent child interventions, parental identity changed. These transformations highlighted the effects of positive collaborative relationships with professionals encouraging parents to return to relational processes engaging with their child.

\section{Implications}

Based on an analysis of the findings there are implications for research and practice.

\section{Research}

While Alex presented with imbalances of communication and behavioural repertoires; problematising his potential to be agentic or meaningful, his atypical voice was regarded as legitimate and prioritised. The most significant point from this research is that by engaging children with communication difficulties, children can tell us what we do not already know. Displacing our adult centric knowledge, the use of puppets avoided languaging the child and enhanced attempts at authenticity.

Based on this research recommendations for future research include the need to focus attention on how nonverbal, prelinguistic children with ASD embody, make sense of and connect with the world (De Jaegher, 2013). Therefore, ongoing investigation of the impact of interventions based on the creative Arts that rely on movement and imitation, is crucial to connect body and mind.

This research set out to explore if creative methods can engage children with ASD. In a sense, puppets as innocuous but 'controllable physical objects' (Trimingham, 2010, p.2) engaged children.

\section{Practice}

As an approach to inclusion, this research sought to reconceptualise Early Years education and Early Intervention spaces as opportunities for participation and engagement. Movement became a central metaphor to describe 
participation and engagement amongst children with and without the label of Autism and their educators and caregivers. Increasingly and to sustain the interest of all children, puppets framed the research activities. Routines involving the puppets became a series of engaged moments that were revealing and evocative. This research highlighted the need for creative pedagogical approaches involving movement, acknowledging the heterogeneity of children with Autism but also the heterogeneity of voice. Children's bodies and minds found expression through movement. Movement is considered a central metaphor in relation to the elicitation and presence of parent voice. Autoethnography uncovered what is universal. While parents encountered inconsistent and incoherent systems and supports, personal transformations were apparent. Parents traversed an elliptical journey returning to that inner relational space of movement and being moved.

In summary, this research has made a contribution to existing research on Early Years education and Early Intervention by advocating the need to specifically address the intersubjective challenges of the nonverbal child with ASD, using the creative Arts. This research has also established that puppetry can be developed as a key instrument in accessing children's worlds. Parent voice was influential. Through movement there is potential to access voice. Children with Autism and their parents can be encouraged not only to 'be' but to 'be with'.

\section{References}

Baron-Cohen, S. (1989). The autistic child's theory of mind: A case of specific developmental delay. Child Psychology \& Psychiatry \& Allied Disciplines, 30(2), 285297. https://doi.org/10.1111/j.1469-7610.1989.tb00241.x.

Bauminger, N., \& Shulman, C. (2003). The development and maintenance of friendship in highfunctioning children with autism: Maternal perceptions. Autism, 7(1), 81-97. https://doi.org/10.1177/136236130 3007001007 .

Caldwell, P. (2010). ASD and Intensive Interaction. London: Jessica Kingsley.
Dawson, G., Munson, J., Estes, A., Osterling, J., McPartland, J., Toth, K., ... Abbott, R. (2002). Neurocognitive function and joint attention ability in young children with autism spectrum disorder versus developmental delay. Child Development, 73(2), 345-358. https://doi.org/10.1111/1467-8624.00411.

De Jaegher, H. (2013). Embodiment and sense-making in autism. Frontiers in integrative neuroscience, 7, 15. https://doi.org/10.338g/fnint.2013.00015.

Deleuze, G., Guattari, F., \& Massumi, B. Nomadology: The war machine. New York: Semiotext (e).

Deleuze, G., \& Guattari, F. (1987). A Thousand Plateaus: Capitalism and Schizophrenia. London: Athlone Press.

Dwight-Salmon, M. (2005). Script training with storybooks and puppets: A social skills intervention package across settings for young children with autism and their typically developing peers. (Tese de Doutorado). The Ohio State University.

Epstein, I., Stevens, B., McKeever, P., Baruchel, S., \& Jones H. (2008). Using puppetry to elicit children's talk for research. Nursing Inquiry, 15(1), 49-56. https:// doi.org/10.1111/j.1440-1800.2008.00395.x.

Escalona, A., Field, T., Nadel, J., \& Lundy, B. (2002). Imitation effects on children with ASD. Journal of ASD and Developmental Disorders, 32, 141-144.

Fuchs, T., \& De Jaegher, H. (2009). Enactive intersubjectivity: Participatory sense-making and mutual incorporation. Phenomenology and the cognitive sciences, 8(4), 465-486. https://doi.org/10.1007/ \$11097-009-9136-4.

Government of Ireland. (2004). Education for Persons with Special Educational Needs (EPSEN) Act. Dublin: Stationery Office.

Government of Ireland. (2005). Disability Act. Dublin: Stationery Office.

Graham, A. \& Fitzgerald, R. (2010). Progressing children's participation: Exploring the potential of a dialogical turn. Childhood, 17(3), 343-359. https://doi. org/10.1177/0907568210369219.

Hobson, R. P. (1993). ASD and the development of mind. Hove: Lawrence Erlbaum.

Hobson, R. P. (2007). On being Moved in Thought and Feeling: An Approach to ASD. In P. M. Gonzales, J. M. Pérez, M. L. Comí, C. Nieto (Eds.). New Developments in ASD: The Future is today. (pp. 139-154). London: Jessica Kingsley.

IngersolL, B. (2012). Brief report: Effect of a focused imitation intervention on social functioning in children with autism. Journal of autism and developmental disorders, 42(8), 1768-1773. https://doi. org/10.1007/s10803-011-1423-6. 
Johora, F. T., Fleer, M., \& Veresov, N. (2019). Inclusion of a child with expressive language difficulties in a mainstream Australian preschool-roundabout ways can create opportunities for participation. International Journal of Inclusive Education, p. 1-18. https://doi. org/10.1080/13603116.2019.1609100.

Jones, P.; \& Gillies, A. (2010). Engaging young children in research about an inclusion project. In R. Rose (Ed.). Confronting obstacles for inclusion-international responses to developing education. (pp. 123-136). London: Routledge. https://doi. org/10.4324/9780203846780.

Kasari, C., Locke, J., Gulsrud, A., \& Rotheram-Fuller, E. (2011). Social networks and friendships at school: Comparing children with and without ASD. Journal of autism and developmental disorders, 41(5), 533-544. https://doi.org/10.1007/s10803-010-1076-X.

Leitch, R., \& Mitchell, S. (2007). Caged birds and cloning machines: how student imagery 'speaks' to us about cultures of schooling and student participation. Improving Schools, 10(1), 53-71. https://doi. org/10.1177/1365480207073722.

Lewis, A. (2010). Silence in the context of 'child voice'. Children \& Society, 24(1), 14-23.

Lewis, A., \& Porter, J. (2007). Research and pupil voice. In L. Florian (Ed.). The SAGE handbook of special education. (pp. 223-234). London: SAGE Publications Ltd. https://doi.org/10.4135/9781848607989.n17.

Long, L., Mcphillips, T., Shevlin, M., \& Smith, R. (2012). Utilising creative methodologies to elicit the views of young learners with additional needs in literacy. Support for Learning, 27(1), 20-28. https://doi. org/10.1111/j.1467-9604.2011.001506.X.

Nadel, J. (2014). How imitation boosts development in infancy and autism spectrum disorder. Oxford: OUP Oxford.

Nadel, J., Aouka, N., Coulon, N., Gras-Vincendon, A., Canet, P., Fagard, J., \& Bursztejn, C. (2011). Yes they can!: An approach to observational learning in low-functioning children with autism. Autism, 15(4), 421-435. https://doi.org/10.1177/1362361310386508.

Ngunjiri, F. W., Hernandez, K.-A. C., \& Chang, H. (2010). Living autoethnography, Connecting life and research. Journal of research practice, 6(1), 1-15.

Parsons, S., Guldberg, K., MacLeod, A., Glenys, J., Prunty, A., \& Balfe, T. (2009). International review of the literature of evidence of best practice provision in the education of persons with autistic spectrum disorders. Ireland: National Council for Special Education. https://doi.org/10.1080/08856257.2011.543534.

Reddy, V. (2008). How infants know -minds. Cambridge: Harvard University Press.

Reddy, V. (2012). Moving others matters. In A. Foolen; U. M. Lüdtke; T. P. Racine; J. Zlatev (Eds.). Moving ourselves, moving others. (pp. 139-164). Amsterdam: John Benjamins Publishing Company. https://doi. org/10.1075/ld.3.3.10gre.
Rochat, P., Passos-Ferreira, C., \& Salem, P. (2009). Three levels of intersubjectivity in early development. Proceedings of the International Workshop "Enacting Intersubjectivity: Paving the way for a dialogue between Cognitive Science, Social Cognition, and Neuroscience". (pp. 173-190). Lugano, Switzerland: Istituto di Psicologia e Sociologia della Comunicazione.

Rose, R., \& Shevlin, M. (2010). Count me in!, Ideas for actively engaging students in inclusive classrooms. [S.L.]: Jessica Kingsley Publishers.

Rose, R., Shevlin, M., Twomey, M., \& Zhao, Y. (2017). Gaining access to support for children with special educational needs in the early years in Ireland, parental perspectives. International Journal of Early Years Education, 25(4), 379-392. https://doi.org/10.10 80/0.966.9760.2017.1321529.

Salmon, M. D., \& Sainato, D. M. (2005). Beyond Pinocchio, Puppets as teaching tools in inclusive early childhood classrooms. Young Exceptional Children, 8(3) p. 12-19. https://doi. org/10.1177/109625060500800303.

Schrandt, J. A., Townsend, D. B., \& Poulson, C. L. (2009). Physical activity in homes 13 teaching empathy skills to children with autism. Journal of Applied Behavior Analysis, 42(1), 17-32. https://doi. org/10.1901/jaba.2009.42-17.

Smith, A. B., \& Taylor, N. J. (2000). Children's voices, Research, policy and practice. New Zealand: Pearson Education,

Sterponi, L., \& Fasulo, A. (2010). "How to go on", Intersubjectivity and progressivity in the communication of a child with autism. Ethos, 38(1), 116-142. https:// doi.org/10.1111/j.1548-1352.2009.01084.X.

Tozer, R. (2003). Involving children with ASD in research about their lives. Methodological issues in interviewing children and young people with learning difficulfies. (pp. 2001-3). Birminghan: University, ESRC.

Trevarthen, C., \& Delafield-Butt, J. T. (2013). Autism as a developmental disorder in intentional movement and affective engagement. Frontiers in Integrative Neuroscience, 7. Article 49, 1-16. https://doi. org/10.3389/fnint.2013.00049.

Trimingham, M. (2010). Objects in transition, The puppet and the autistic child. Journal of Applied Arts \& Health, 1(3), 251-265. https://doi.org/10.1386/ jaah.1.3.251_1.

Twomey, M. (2016). Transitions, Space and Place. Children's Research Digest, 3(2), 1-7.

Twomey, M. (2018). Embodied Voice: Children speak through their bodies. In Twomey, M.; Carroll, C. (Eds). 'Seen and Heard' Researching with Children, An interdisciplinary approach to exploring children's participation, engagement and voice. United Kingdom: Peter Lang.

Twomey, M., \& Shevlin, M. (2017). Parenting, autism spectrum disorders and inner journeys. Journal of Research in Special Educational Needs, v. 17, (3), 157167. https://doi.org/10.1111/1471-3802.12373. 
United Nations. Committee on the Rights of the Child. (1989). Convention on the Rights of the Child. Geneva: United Nations. https://doi.org/10.1007/ springerreference_301090.

Wimpory, D. C., Hobson, R. P., \& Nash, S. (2007). What facilitates social engagement in preschool children with autism?. Journal of Autism and Developmental Disorders, 37(3), 564-573. https://doi.org/10.1007/ s10803-006-0187-X.

Winnicott. D. W. (1971). Playing and Reality. New York: Basic Books.

Wolfberg, P., Bottema-Beutel, K., \& Dewitt, M. (2012). Including Children with Autism in Social and Imaginary Play with Typical Peers, Integrated Play Groups Model. American Journal of Play, 5(1), p. 55-80. https://doi.org/10.1037/e669652011-001.

\begin{abstract}
About the author:
Miriam Twomey has a background in teaching and research in the fields of Early Intervention, Autism Spectrum Disorders and Intellectual and Developmental disabilities. Miriam completed her M. Litt and Doctoral Degrees at the School of Education, Trinity College Dublin and has worked as a Post Doctoral research associate, lecturer and research supervisor there. Miriam holds the position of Assistant Professor in Early Intervention at the Centre for People with Intellectual Disabilities (TCPID), at the School of Education, Trinity College Dublin. Miriam is leading the Masters in Education [Early Intervention] which is designed to provide post graduate level study for those who wish to develop or enhance knowledge and experience working with young children with disabilities or at risk of developing additional needs and/or Special Educational Needs (SEN) in the 0-6 age group.
\end{abstract}

\title{
Mailing Address:
}

Dr Miriam Twomey

School of Education, The Arts Block, Trinity College Dublin,

The University of Dublin, College Green,

Dublin 2, Ireland. 